\author{
V.E. Medvedev ${ }^{1}$ and I.V. Filatova ${ }^{2}$ \\ ${ }^{1}$ Institute of Archaeology and Ethnography, \\ Siberian Branch, Russian Academy of Sciences, \\ Pr. Akademika Lavrentieva 17, Novosibirsk, 630090, Russia \\ E-mail: medvedev@archaeology.nsc.ru \\ ${ }^{2}$ Amur State University for Humanities and Pedagogy, \\ Kirova 17, bldg. 2, Komsomolsk-on-Amur, 681000, Russia \\ E-mail:inga-ph@mail.ru
}

\title{
Archaeological Findings on Suchu Island (Excavation Area I, 1975)
}

This study describes the finds from dwelling B excavated in 1975 on Suchu Island, near Mariinskoye, Khabarovsk Territory. Lithics, ceramics, portable objects of art, and ritual artifacts (the total of 11,574 items) are housed at the Institute of Archaeology and Ethnography SB RAS. Excavations in area I have been carried out since 1972 in an extension of dwelling $B$, which had been partially unearthed previously. In 1975, $252 \mathrm{~m}^{2}$ were cleared, finishing the works in excavation area I. Stratigraphic and planigraphic methods were used to reconstruct the layout of the dwelling and the space outside it. A morphological classification of the lithics was undertaken, ceramics were studied with a binocular microscope, and the chronology of all finds was evaluated. Some of these date to the Middle Neolithic (Malyshevo and Kondon cultures, and the Belkachi complex), some to the Late Neolithic (Voznesenovskoye culture) and Final Neolithic, some to later periods, such as the Bronze Age, Early Iron Age, or the Middle Ages. Lithics include tools and debris. Ceramics, objects of art, and ritual items mostly represent the middle stage of the Malyshevo culture. Two burials, dating to the Neolithic and the Early Iron Age, were found inside dwelling B. They were arranged after the dwelling had been abandoned, and they are especially relevant to cultural and historical reconstructions, since ancient burials are very rare in the region, and not a single one dating to the Neolithic was known until the present time.

Keywords: Amur basin, Suchu, Neolithic, dwellings, artifacts, interdisciplinary approach.

\section{Introduction}

In 1975, studies of the ancient dwelling on Suchu Island, near Mariinskoye, in the Khabarovsk Territory, were continued*. Excavations in area I, conducted

* The excavations in 1975 were carried out by A.P. Okladnikov (head of expedition), V.E. Medvedev (head of party), M.D. Brilliant, V.N. Kopytko, A.K. Konopatsky, and a group of students of the Khabarovsk State Pedagogical Institute. since 1972 (Okladnikov, Medvedev, Filatova, 2015), have been carried out in the depression that is an extension of dwelling $B$, which had been revealed and partially unearthed previously (Okladnikov, 1973, 1980; Medvedev, Filatova, 2016). The excavation area is $252 \mathrm{~m}^{2}$ (Fig. 1, $A-E$ ), designations of grids continued the system of previous years: numerical ones, from south to north (from 37 to 55), and alphabetical ones, from line A westward to X. To establish stratigraphy, two baulks were left (Fig. 1, F, G).

Archaeology, Ethnology \& Anthropology of Eurasia 47/4 (2019) 30-42 E-mail: Eurasia@archaeology.nsc.ru (C) 2019 Siberian Branch of the Russian Academy of Sciences

(C) 2019 Institute of Archaeology and Ethnography of the Siberian Branch of the Russian Academy of Sciences (C) 2019 V.E. Medvedev, I.V. Filatova 
The discovered artifacts were recorded on layerby-layer plans (Fig. 1, $A-D$ ). In total, 11,574 items of lithics (2079), ceramics (9260), household items (198), and objects of art and cult have been found. These studies have completed the stationary works in excavation area I on Suchu Island.

We have studied the earlier undescribed archaeological materials obtained in 1975 (lithics, ceramics, objects of art, and ritual items), and also field documents (list of finds, diaries, drawings). Methods of stratigraphy and planigraphy (dwellings and space between the dwellings), morphotypology (lithics), binocular microscopy (ceramics), and cultural chronology (ceramics, objects of art and cult) were used.

\section{Stratigraphy}

The north-south brow along line $H$ (Fig. 1, F). Layer 1 (ca 15-20 cm thick) is a tight dark brown soil with an admixture of sand. Layer $2(10-15 \mathrm{~cm})$ is a friable (less tight than layer 1) brown soil. Layer 3 (ca 10-15 cm) is tighter than layer 2, dark brown; it is a buried soil. Layer $4(15-20 \mathrm{~cm})$ differs from the overlying strata in its light yellow color; its upper boundary is smooth, and the lower one is wavy; enriched in sand; separate stones are encountered. Layer $5(20-40 \mathrm{~cm})$ is darker than layer 4 , and lies almost horizontally, only slightly lowering towards the center and wedging out towards the edges. Layer $6(40-90 \mathrm{~cm})$ is an extension to layer 5, though significantly darker in color (dark brown); sometimes, separate rather large pieces of coal occur. Layer $7(40-100 \mathrm{~cm})$ is considerably lighter than two overlying ones, but also wedges out towards the edges (walls of the dwelling pit). Layer $8(20-25 \mathrm{~cm})$ is darker, almost black, loose in places; separate pieces of coal occur. Layer 9 is a grayish-yellow sandy loam interlayer overlying a yellow bedrock sandy loam near the pit wall. Layers 10-12 form the filling of the lower part of the foundation pit; this is a dark yellow sandy loam (layers 10,12) separated in the middle by a coaly (without coal pieces) earth lens (layer 11) ca $10-15 \mathrm{~cm}$ thick.

The east-west baulk along line 46 (Fig. 1, G). In its content, it is similar to the above baulk. A wavy upper sand layer was drifted down from above along the ravine. A brown soil is recorded below it (layer 2). Deeper, a dark brown soil (layer 3) is noted, which was formed at the place of an old horse stable (?) of the 19th century; below it, there is a dark yellow sandy loam (layer 4), and a yellow soil (layer 5). The reference horizon (layer 6) is a buried soil at the place of the already covered pit of a Neolithic dwelling; it wedges out towards the pit's edges, and becomes thicker with the slope of its surface. A sequence of ancient filling lies below. Layer 7 is composed of loose light brown sandy loam. Layer 8 is darker, since it is enriched in humus. Possibly it was formed as a result of wooden roof collapse. Layers 7 and 8 wedge out towards the pit walls. The upper part of the pit wall near the baulk edge is overlapped by a loose dark yellow sandy loam (layer 9), which probably slipped down from the collapsed roof of the dwelling.

\section{Dwelling $B$}

The pit of the dwelling (Fig. 1,E) was let into light yellow fine-grained bedrock sand to a depth of $3.0 \mathrm{~m}$ from the modern daylight surface. The dwelling itself was arranged as an amphitheater: its walls went down to the floor through five ledges in the western part, and six in the eastern one. The floor's area is about $8.2 \mathrm{~m}^{2}$. Here, hearth stones and pieces of charcoal were found on the native soil. The height of the first (counting from low to high) ledge with a horizontal surface is about $40 \mathrm{~cm}$. The second also has a horizontal surface, an upright wall, and a height of about $45 \mathrm{~cm}$. The third ledge is a flat level surface ca $1 \mathrm{~m}$ wide. Its wall is about $35-40 \mathrm{~cm}$ high, steep, indistinct in places. The fourth ledge is rather well-defined. Its feature is the presence of protrusions and "niches". The maximum width of the ledge is ca $1.5 \mathrm{~m}$, the wall height is ca $40 \mathrm{~cm}$. In the southern part, the last wall merged with the wall of the fifth ledge. In the fifth ledge, there were two cup-shaped depressions up to $1.0 \mathrm{~m}$ in diameter and, presumably, a hearth pit ca $35 \mathrm{~cm}$ deep, with upright walls and a flat bottom. In the southern part, the fifth ledge merged into the sixth one. The dwelling showed seven "niches", especially dug in its stepped walls to a depth of 0.3 to $1.5 \mathrm{~m}$.

The architectural features of dwelling $B$ are generally identical to those recorded during excavations of other residential buildings on the island (Derevianko, Medvedev, 2002; Okladnikov, Medvedev, Filatova, 2015; Medvedev, Filatova, 2016, 2018a). However, this dwelling, rounded in plan view, is one of the largest (up to $16 \mathrm{~m}$ in diameter) and deepest (about $3 \mathrm{~m}$ from the modern surface). As noted above, its distinctive feature is the presence of protrusions that served probably as some sort of bunks and/or shelves, 
$\begin{array}{lllllll}52 & 51 & 50 & 49 & 48 & 47 & 46\end{array}$

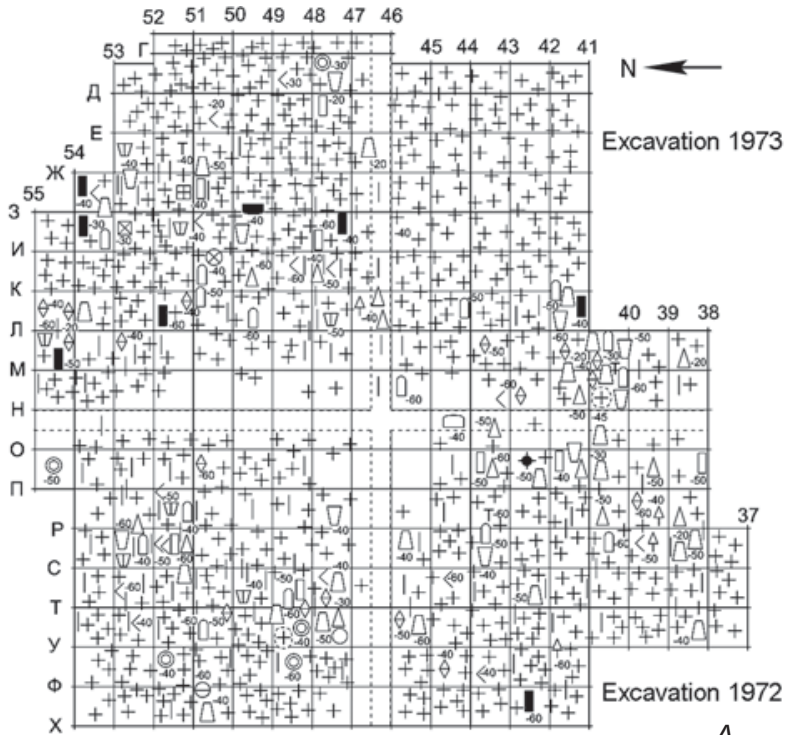

$\begin{array}{lllllll}52 & 51 & 50 & 49 & 48 & 47 & 46\end{array}$

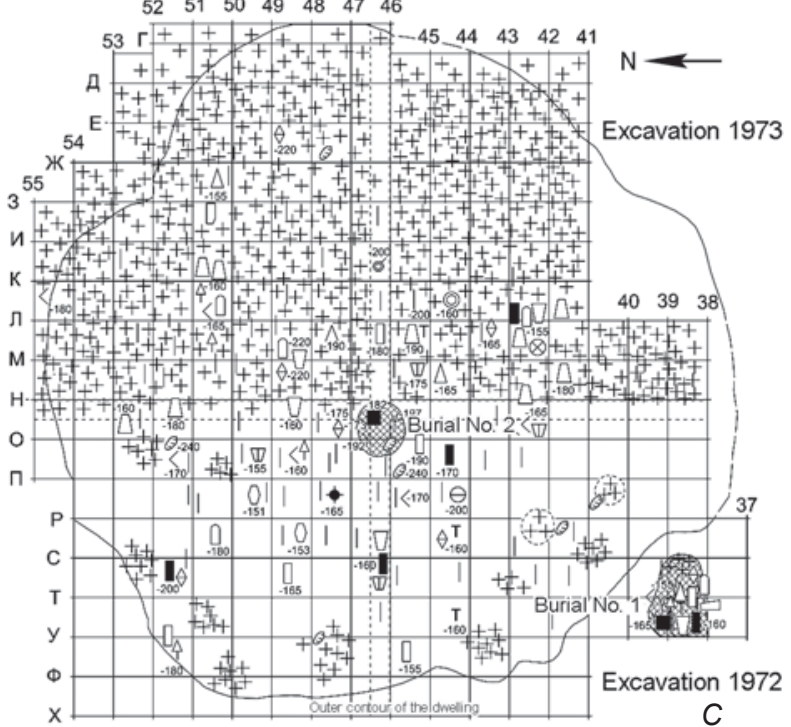

$\begin{array}{lllllll}52 & 51 & 50 & 49 & 48 & 47 & 46\end{array}$

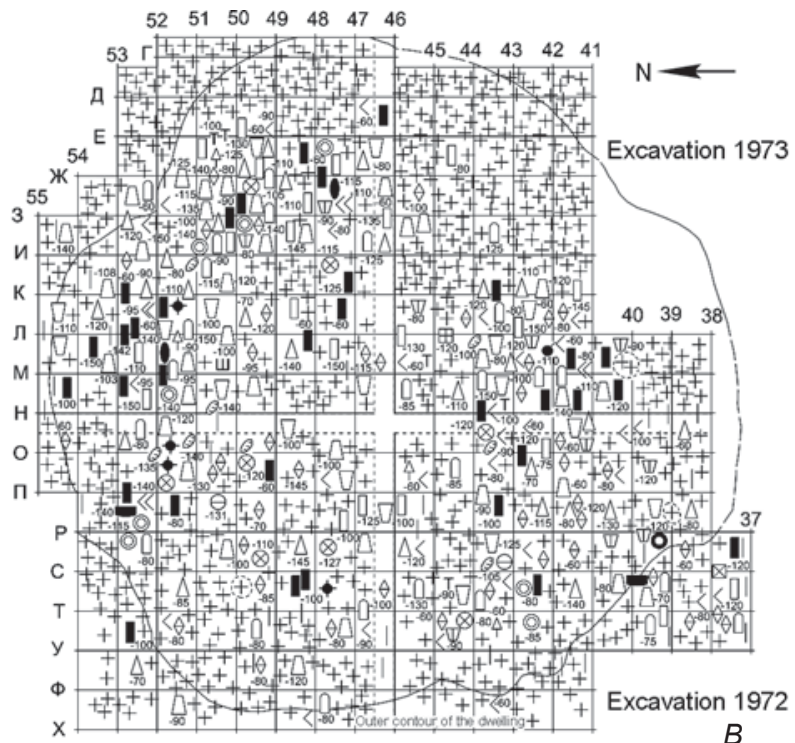

$B$

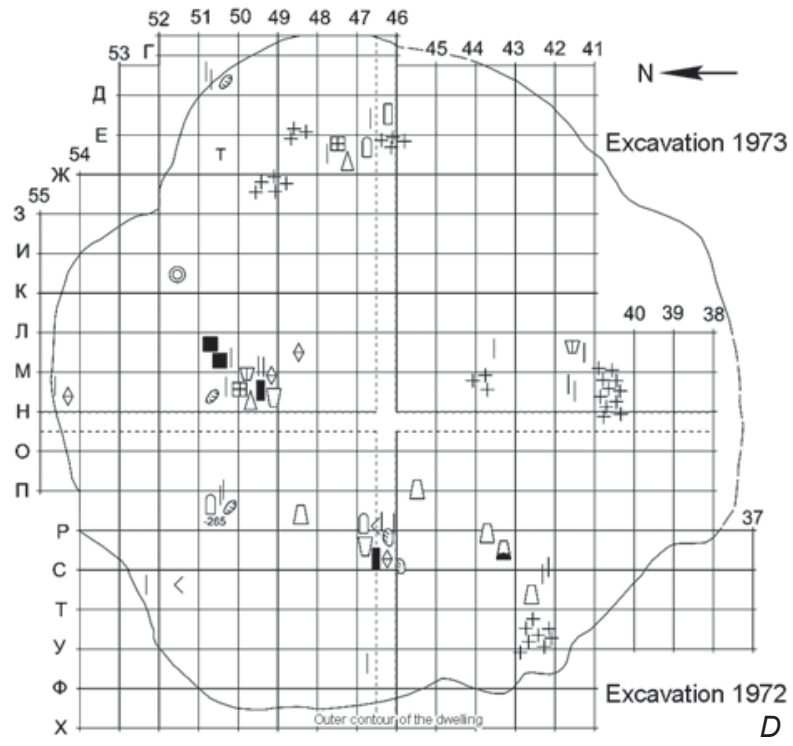

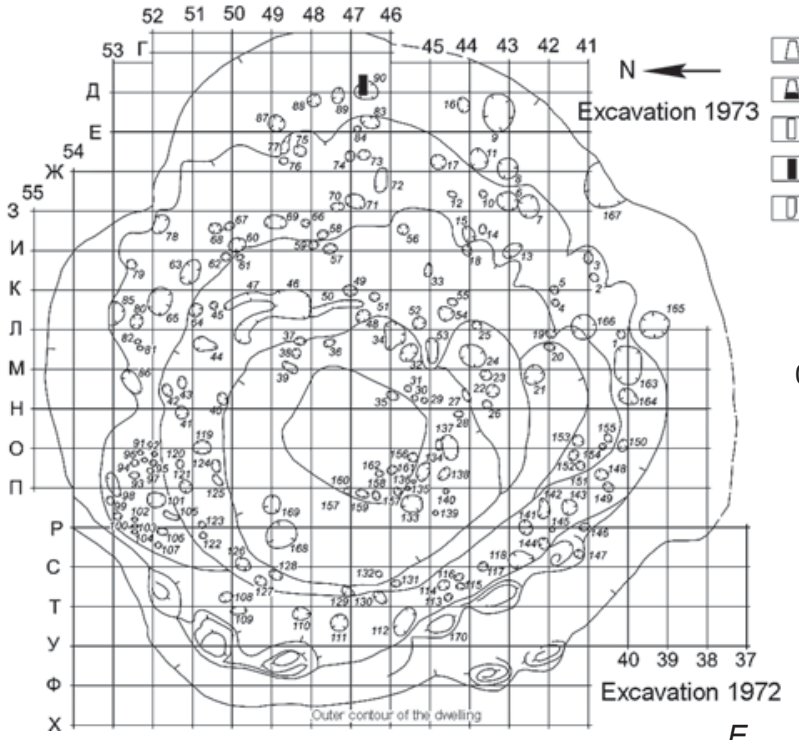

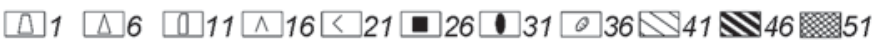

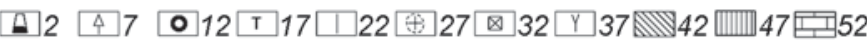

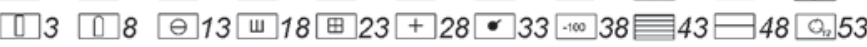

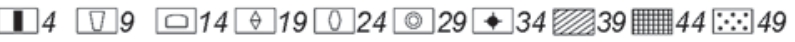

$\square 5 \square 10 \square 15 \square 20 \square 25 \otimes 30 \square 35 \square 40 \square 45-50$
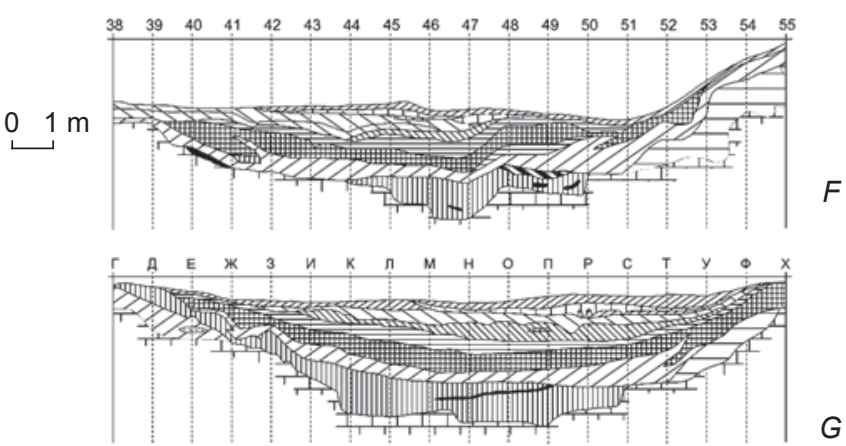
Fig. 1. Plans of a part of excavation area I (1975) at the levels of upper layer $(A)$, filling of dwelling $(B, C)$, above and on the floor $(D)$, native soil $(E)$, and sections of the baulks along lines $\mathrm{H}(F), 46(G)$.

1 - an adze, an axe, a heavy-duty tool; 2 - a chisel; 3 - a knife; 4 - a knife-shaped blade; 5 - an inset; 6 - a dart, an arrowhead; 7 - a borer; 8 - an end-scraper, a side-scraper; 9 - a combination tool; 10 - a saw; 11 - a percussive tool; 12 - a mace; 13 - a lead weight; 14 - a stone with a hole; 15 - a hammerstone, a crutch; 16 - a burnisher (stone); 17 - a whetstone; 18 - a polishing-slab; 19 - a blank of tool; 20 - a core, a core-shaped item; 21 - a core-shaped spall; 22 - a flake; 23 - a pebble with spalls; 24 - a stone item; 25 - a pendant (stone); 26 - a vessel (fragmented); 27 - an accumulation of ceramics; 28 - ceramics; 29 - a spindle whorl; 30 - a clay item; 31 - a ceramic rod; 32 - a ceramic stamp; 33 - a burnisher (ceramic); 34 - a clay figurine, craft; 35 - a pendant (ceramic); 36 - a stone; 37 - bones, teeth; 38 - a depth from the modern daylight surface; 39 - dark brown sandy loam; 40 - brown soil; 41 - dark brown ground (buried soil); 42 - light yellow sandy loam; 43 - yellow ground; 44 - deep-brown ground (buried soil); 45 - light brown sandy loam; 46 - dark, almost black soil; 47 - grayish-yellow sandy loam; 48 - rather loose dark yellow sandy loam; 49 - calcined sand; 50 - an accumulation of coals, carbon-bearing interlayer; 51 - filling of burials; 52 - native soil; 53 - a pit.

and also "niches" where various domestic appliances could be placed.

Noteworthy is the pit noted in grid 38, 39/C, T. A large gray spot was cleaned out, and a darker one on top of it, a coaly-sooty oval, oriented with its long axis along the east-west line. A pit $42-45 \mathrm{~cm}$ deep, partially filled with coaly-sooty material, was under this spot. Below, in gray filling in the west part of the pit, a broken red-burnished vessel decorated with imprints of retreating spatula, a carnelian knife-biface, and small flint flakes were found; in the middle part, fragments of another red-burnished vessel were revealed. A crushed bowl, four miniature vessels, a knife-like blade, flakes, a flinty arrowhead, a borer, and an endscraper were found 10-12 cm lower. In the pit's filling, small splinters of burned bones, obviously remains of a Neolithic burial made according to the cremation ritual, were recorded.

Another incineration was revealed in grid 45, $46 / \mathrm{H}$, O. At a depth of 170-200 cm from the modern daylight surface, under a tight coaly layer containing charcoal pieces, a lens of dark coaly soil oval in plan view was found. It is a cup-shaped pit filled with black, tight earth. A burned-out piece of birch with birch-bark, chipped and burned stones, a fragment of obviously human loose bone, and pieces of a human mandible $40-45 \mathrm{~cm}$ from it, were found here. Also, fragments of vessel with imprints of finger cushions, typical of the Poltse culture of the Early Iron Age, were discovered in the pit. A burial made according to the incineration rite was performed in the dwelling filling, most probably ca $2 \mathrm{ka} \mathrm{BP}$.

In the excavation area, 169 pits were revealed, the vast majority of which proved to be within the dwelling (Fig. 1,E). These are mainly rounded or ovalshaped in plan view, small $(10-15 \mathrm{~cm})$ or medium $(20$ $40 \mathrm{~cm})$ in size, and are from rather shallow $(5-10 \mathrm{~cm})$ or medium $(20-40 \mathrm{~cm})$ to rather deep $(60-70 \mathrm{~cm})$. These holes are predominantly from the posts that constituted the support base of the dwelling's structure. Larger pits (from $50 \mathrm{~cm}$ to $1 \mathrm{~m}$ in size, and from 20
30 to $60-70 \mathrm{~cm}$ in depth) that can be assigned to the household are also noted.

At a level of $60 \mathrm{~cm}$ from the modern surface, in some places, the outer native-soil contour of the dwelling pit showed up; therefore, the finds discovered above this level were marked at the first plan (Fig. 1, $A$ ). The upper layer was predominantly a humic black soil. Artifacts were uniformly distributed throughout the entire area. Finds discovered deeper than $60 \mathrm{~cm}$ from the surface were marked in the second and third layerby-layer plans (Fig. 1, B, C). The bulk of these finds were contained in layers $7-9$.

\section{Lithics}

In total, there are 2082 lithic artifacts in the collection from the 1975 excavation area (Table 1, 2; Fig. 2)*.

The lithics discovered within the dwelling pit consist of the primary reduction materials (1531 spec.), instruments (19 spec., including debris), and tools (396 spec., including debris and blanks). The distribution of the artifacts by layers has demonstrated that the bulk of finds originate from the upper (986) and lower (400) parts of the filling, and also from the upper layer (478). A rather small number of items (85) have been found above the floor, immediately on the floor, or in the pits.

The lithics discovered outside the dwelling consist mainly of the primary reduction materials (99), a small quantity of instruments (2), and tools (32, including debris and blanks). The distribution of finds by layers is roughly the same. Noteworthy are lithic artifacts from the Neolithic burial. In total, 78 items were discovered there, $2 / 3$ of which are the materials of primary reduction.

*A special study is devoted to description of the lithics discovered in excavation area I in 1975 (Medvedev, Filatova, 2018b). 
Table 1. Lithics from the dwelling

\begin{tabular}{|c|c|c|c|c|c|}
\hline Type of lithics & $\begin{array}{l}\text { Upper layer } \\
\text { (above } \\
60 \mathrm{~cm}^{*} \text { ) }\end{array}$ & $\begin{array}{l}\text { Upper part of } \\
\text { filling } \\
(61-150 \mathrm{~cm})\end{array}$ & $\begin{array}{l}\text { Lower part of filling } \\
\quad(151-250 \mathrm{~cm})\end{array}$ & $\begin{array}{l}\text { Above the floor, } \\
\text { on the floor, and in } \\
\text { the pit (No. 90) of } \\
\text { the dwelling }\end{array}$ & Total \\
\hline 1 & 2 & 3 & 4 & 5 & 6 \\
\hline \multicolumn{6}{|c|}{ Primary reduction materials } \\
\hline Core & 3 & 4 & 1 & 1 & 9 \\
\hline Microcore & 5 & 6 & 3 & 3 & 17 \\
\hline Core-shaped fragment & 15 & 37 & 12 & 2 & 66 \\
\hline Flake & 261 & 543 & 190 & 22 & 1016 \\
\hline Blade & $4 / 2$ & $21 / 8$ & $1 / 2$ & $3 / 0$ & $29 / 12$ \\
\hline Chopped pebble & 1 & 2 & 1 & 4 & 8 \\
\hline Splinter & 78 & 149 & 119 & 28 & 374 \\
\hline Total & 369 & 770 & 329 & 63 & 1531 \\
\hline \multicolumn{6}{|c|}{ Instruments } \\
\hline Hammerstone & $1 / 0 / 0$ & - & - & - & $1 / 0 / 0$ \\
\hline Hammerstone-anvil & $1 / 0 / 0$ & - & - & - & $1 / 0 / 0$ \\
\hline Burnisher & - & $1 / 0 / 0$ & $1 / 0 / 0$ & - & $2 / 0 / 0$ \\
\hline Grindstone & $3 / 1 / 0$ & $4 / 1 / 0$ & $3 / 0 / 0$ & $0 / 1 / 0$ & $10 / 3 / 0$ \\
\hline Grinding slab-anvil & $1 / 0 / 0$ & - & - & - & $1 / 0 / 0$ \\
\hline Polishing slab & - & $1 / 0 / 0$ & - & - & $1 / 0 / 0$ \\
\hline Total & 7 & 7 & 4 & 1 & 19 \\
\hline \multicolumn{6}{|c|}{ Tools } \\
\hline Dart & $0 / 3 / 0$ & $1 / 11 / 0$ & $0 / 4 / 0$ & - & $1 / 18 / 0$ \\
\hline Arrowhead & $2 / 6 / 0$ & $12 / 6 / 3$ & $10 / 3 / 0$ & $2 / 0 / 0$ & $26 / 15 / 3$ \\
\hline Knife & $7 / 4 / 3$ & $13 / 11 / 6$ & $3 / 4 / 1$ & $1 / 2 / 0$ & $24 / 21 / 10$ \\
\hline Inset & - & - & $1 / 0 / 0$ & - & $1 / 0 / 0$ \\
\hline Axe & $0 / 1 / 0$ & $4 / 4 / 2$ & - & - & $4 / 5 / 2$ \\
\hline Adze & $6 / 13 / 2$ & $10 / 19 / 3$ & $8 / 1 / 0$ & $3 / 1 / 0$ & $27 / 34 / 5$ \\
\hline Chisel & - & - & - & $1 / 0 / 0$ & $1 / 0 / 0$ \\
\hline $\begin{array}{l}\text { Adze-shaped side-scraper } \\
\text { tool }\end{array}$ & $1 / 0 / 0$ & $4 / 0 / 0$ & - & - & $5 / 0 / 0$ \\
\hline End-scraper & $15 / 1 / 7$ & $23 / 0 / 21$ & $9 / 0 / 6$ & $2 / 0 / 3$ & $49 / 1 / 37$ \\
\hline Side-scraper & $1 / 0 / 0$ & $3 / 0 / 0$ & $1 / 0 / 0$ & - & $5 / 0 / 0$ \\
\hline Borer & $3 / 0 / 3$ & $4 / 0 / 2$ & $3 / 0 / 0$ & - & $10 / 0 / 5$ \\
\hline Point & - & $1 / 0 / 0$ & - & - & $1 / 0 / 0$ \\
\hline Combination tool & $9 / 1 / 0$ & $10 / 0 / 0$ & $2 / 0 / 0$ & $2 / 0 / 0$ & $23 / 1 / 0$ \\
\hline Lead weight-anchor & - & - & $1 / 0 / 0$ & - & $1 / 0 / 0$ \\
\hline Lead weight & $0 / 1 / 0$ & $0 / 1 / 0$ & $0 / 1 / 0$ & - & $0 / 3 / 0$ \\
\hline Mace & - & $0 / 1 / 0$ & $0 / 1 / 0$ & - & $0 / 2 / 0$ \\
\hline Percussive tool & - & - & - & $1 / 0 / 0$ & $1 / 0 / 0$ \\
\hline Stone with a hole & $0 / 1 / 0$ & - & - & - & $0 / 1 / 0$ \\
\hline Retouched blade & - & $5 / 1$ & $1 / 0$ & - & $6 / 1$ \\
\hline Retouched flake & $12 / 0$ & $27 / 1$ & $4 / 0$ & $3 / 0$ & $46 / 1$ \\
\hline Total & 102 & 209 & 64 & 21 & 396 \\
\hline
\end{tabular}


Table 1 (end)

\begin{tabular}{|c|c|c|c|c|c|}
\hline 1 & 2 & 3 & 4 & 5 & 6 \\
\hline \multicolumn{6}{|c|}{ Non-utilitarian items } \\
\hline Ring pendant & - & - & $0 / 1 / 0$ & - & $0 / 1 / 0$ \\
\hline "Male-female" sculpture & - & - & $0 / 2 / 0$ & - & $0 / 2 / 0$ \\
\hline Total & 0 & 0 & 3 & 0 & 3 \\
\hline In all & 478 & 986 & 400 & 85 & 1949 \\
\hline
\end{tabular}

Note. The first digit is the number of intact pieces, the second digit is the number of fragments, and the third digit is the number of blanks.

*From the modern surface.

Table 2. Lithics from the space between dwelling and from the burial in the dwelling filling*

\begin{tabular}{|c|c|c|c|c|}
\hline Type of lithics & Above $60 \mathrm{~cm}$ & $61-100 \mathrm{~cm}$ & Burial & Total \\
\hline \multicolumn{5}{|c|}{ Primary reduction materials } \\
\hline Core-shaped fragment & 1 & 1 & 3 & 5 \\
\hline Flake & 18 & 10 & 28 & 56 \\
\hline Blade & 1 & - & 4 & 5 \\
\hline Splinter & 7 & 4 & 22 & 33 \\
\hline Total & 27 & 15 & 57 & 99 \\
\hline \multicolumn{5}{|c|}{ Instruments } \\
\hline Grindstone & - & - & $0 / 2 / 0$ & $0 / 2 / 0$ \\
\hline Total & 0 & 0 & 2 & 2 \\
\hline \multicolumn{5}{|c|}{ Tools } \\
\hline Dart & - & - & $0 / 1 / 0$ & $0 / 1 / 0$ \\
\hline Arrowhead & - & - & $1 / 0 / 0$ & $1 / 0 / 0$ \\
\hline Knife & - & $0 / 2 / 0$ & $2 / 1 / 0$ & $2 / 3 / 0$ \\
\hline Saw & - & - & $1 / 0 / 0$ & $1 / 0 / 0$ \\
\hline Axe & $1 / 0 / 0$ & - & - & $1 / 0 / 0$ \\
\hline Adze & $1 / 1 / 0$ & $1 / 1 / 0$ & - & $2 / 2 / 0$ \\
\hline End-scraper & - & $1 / 0 / 2$ & $1 / 0 / 5$ & $2 / 0 / 7$ \\
\hline Side-scraper & - & $1 / 0 / 0$ & - & $1 / 0 / 0$ \\
\hline Borer & $1 / 0 / 0$ & - & $1 / 0 / 0$ & $2 / 0 / 0$ \\
\hline Combination tool & - & - & $2 / 0 / 0$ & $2 / 0 / 0$ \\
\hline Retouched flake & $1 / 0$ & - & $4 / 0$ & $5 / 0$ \\
\hline Total & 5 & 8 & 19 & 32 \\
\hline In all & 32 & 23 & 78 & 133 \\
\hline
\end{tabular}

*See note to Table 1.

\section{Ceramics}

The ceramic collection from the excavation area contains 9261 items: vessels (19 spec. have been reconstructed) and fragments thereof (9044), and also clay articles (198). Ceramics have been discovered in the upper layer of the excavation area, in the upper and lower parts of the filling, under the floor and on the floor of the dwelling, and also in the space outside it. The recovered ceramic pieces have been attributed mainly to the Middle (Malyshevo, Kondon, and Belkachi cultures), Late (Voznesenovskoye culture), and Final Neolithic periods. There are some specimens from the Bronze Age, the Early Iron Age, and the Middle Ages, as well as fragments that cannot be identified with Amur pottery. 


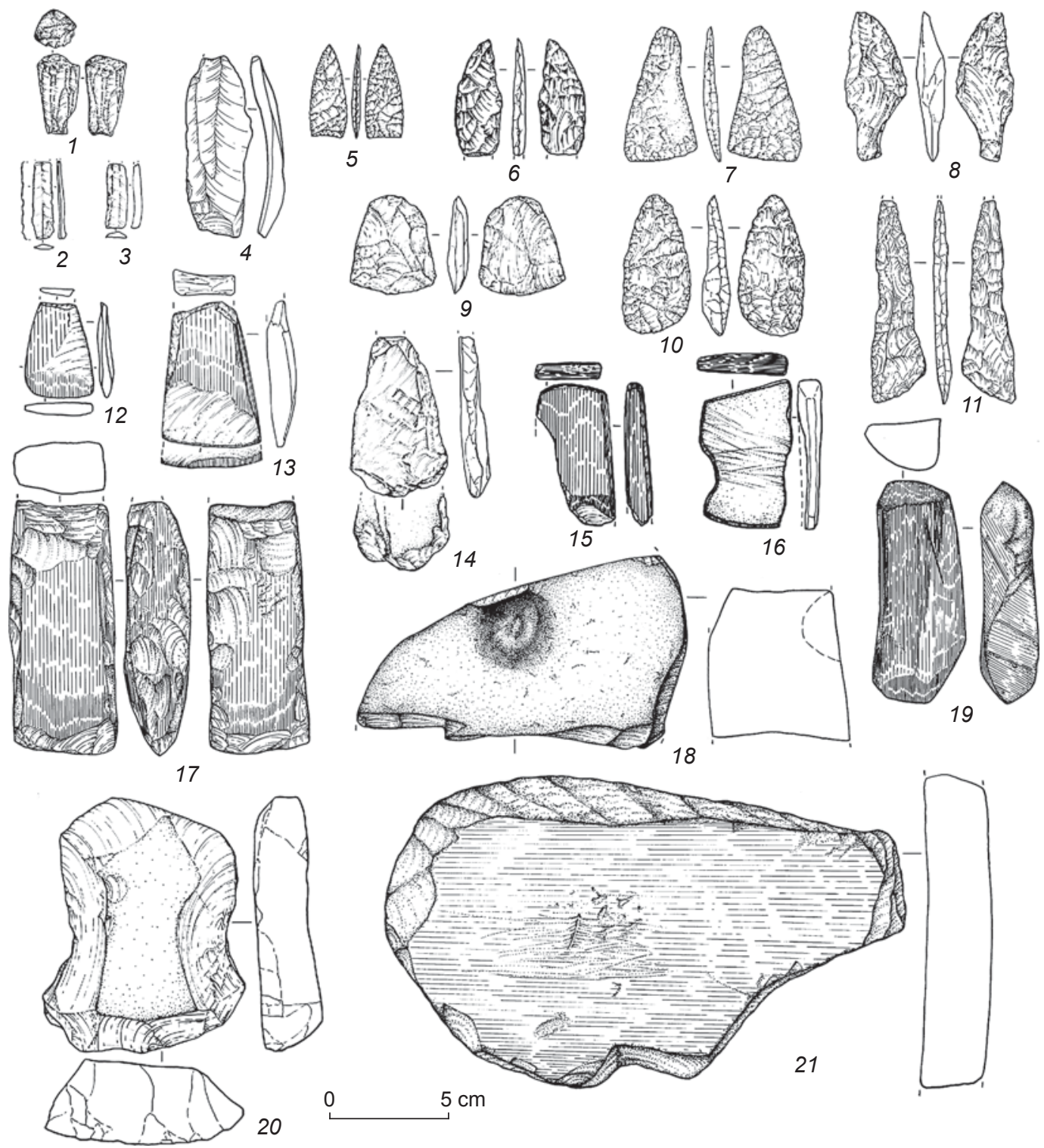

Fig. 2. Stone tools.

1 - a core; 2-4 - knife-shaped blades; 5 - an arrowhead; 6-8, 10 - knives; 9 - an end-scraper; 11 - a combination tool; 12-14, 17 - adzes; 15,16 - burnishers; 18 - a stone with a hole; 19 - a grindstone; 20 - a side-scraper tool; 21 - a grinding slab-anvil.

The Malyshevo culture (Fig. 3, 1-18) is represented by 7527 items: 13 vessels (reconstruction), 358 upper and 35 lower parts, 4 side pieces, 875 rims, 5749 walls, and 493 bottoms. These items have been found in the upper layer (2439), in the upper (3663) and lower (975) parts of the filling, above the floor (25) and on the floor (350) of the dwelling, in pits (42), and also in the Neolithic burial (33). The ceramic paste of fragments is mainly rather dense and tempered with grog. Vessels were shaped using base-, base-and-body, or body-andbase shaping methods, as well as coil-ring technique. There are items with and without necks, with open and closed shapes, and ranging from miniature to large in size. The rims of the vessels are straight or folded outor inwards; upper cuts are rounded, pointed, flattened, or beveled. Almost all bottoms are flat; only one pointed-bottom vessel is recorded (Medvedev, 2017: 157, fig. 1).

The surfaces of ready items were rubbed, smoothed, burnished, possibly covered with engobe, "smoked", and painted red from outside and/or inside. The vessels varied in color from light (yellow, reddish, orange, or light brown) to dark (dark brown or dark gray, nearly black) tones, which shows that the firing mode was oxidizing. Ornamentation consists of deepened and convex relief, or flat decoration patterns. The basic 
technical and decorative elements are comb imprints with two to five cogs, and imprints of retreating spatula (angular and bracket-like). There are also imprints of variously shaped cogged wheels, finger and nail imprints, appliquéd fillets (straight, wavy), incised lines and grooves, and various scratches and pricks. Separate elements form various motifs and simple or complex ornamental compositions. Some pieces (1228 spec., or $16.3 \%$ ) are not decorated. There are household (with carbon deposits) and ritual (including painted) ceramics. Also, burnishers (nine intact ones and three fragments) and their blanks (131 and 8), spindle whorls (five intact and four fragments) and their blanks (12 and 21) from vessel walls (Fig. 3, 8, 10, 12, 15) have been found. The majority of ceramics show consistent technological, morphological, and decorative features, and in general represent a single complex in the developed stage of pottery tradition. At the same time, two separate groups of ceramics can be identified. The first (101 spec.) is composed of the so called Boisman ceramics, with specific ornamentation. The second group (198 spec.) shows pottery pastes with inclusion of freshwater mollusk shells.

The Kondon culture (Fig. 3, 19-25) is represented by 436 items: 8 upper and 3 lower parts, 11 rims, 319 walls, and 95 bottoms. These items have been found in the upper layer (184), in the upper (188) and lower (45) parts of the filling, above the floor (2) and on the floor (16) of the dwelling, and in the pit (1). Most pieces (335 spec., or $76.8 \%$ ) are not decorated. The ceramic paste of fragments is mainly dense, "rigid", and tempered with sand and grus. Vessels were shaped using base-, base-and-body (mainly), body-, or bodyand-base (very rarely) shaping methods, as well as coil-ring, coiling (more rarely), and probably patch technique. The average thickness of rims, walls, and bottoms is $0.6-0.8 \mathrm{~cm}$. Owing to the state of preservation of the Kondon ceramics, we cannot precisely characterize their shapes and sizes; it can be only assumed that these are vessels of closed type, with or without necks, in small, medium, or large sizes. The rims are slightly folded outward, with a rounded or flattened cut. The surfaces of items were rubbed, smoothed, covered with engobe, and "hardened". The ceramics were fired in the redox environment; their colors are brown, dark brown, or dark gray.

All vessels are of household type: soot and sometimes heavy carbon deposits can be observed on the inner side. Three groups can be distinguished with respect to decoration. The first group is characterized by comb imprints (with three to five cogs) and pricks along the cut and exterior surface of the rim, comb imprints (with five to seven and nine cogs), and figured stamp imprints (rhomboids, ovals) on the body; the second group by straight rows of comb imprints (three to five $\operatorname{cogs}$ ) along the mouth cut, below it, and on the body; and the third one by comb imprints with three to four cogs along the mouth cut, and by combinations of horizontal and vertical imprints of comb and/or figured stamp (rhomboids, ovals) on the body. Two unornamented wall fragments of different vessels are blanks of spindle whorls. One more fragment of the near-bottom part was rejuvenated into a sidescraper. The Kondon ceramics is consistent in their technological features. In terms of chronology, this is most probably the end of the late stage.

The Belkachi complex (Fig. 3, 26-28) consists of 139 items: 4 upper parts, 21 rims, and 114 walls (including two near-bottom ones). The items have been found in the upper layer (42), in the upper (79) and lower (11) parts of the filling, and on the floor (7) of the dwelling. The paste is predominantly dense and tempered with grus. Vessels were shaped using coilring technique. The vessels are open or closed, with slightly marked necks, medium and large in size. The rims are straight, slightly folded out- or inwards, with appliquéd fillets. They are decorated with oblique rows of cogged-wheel imprints or multi-cogged comb imprints, arranged parallel to each other or forming "herringbones" or a net. The walls of vessels are covered with vertical cord imprints. Surfaces of ready items were rubbed, "smoked", and covered with engobe. Some fragments show carbon deposits on their inner and outer surfaces. This is most probably the ware for cooking, food storage, and eating. The household use of pottery is also indicated by the fact that one sherd of a vessel wall was used as a burnisher. As mentioned earlier, the Belkachi complex can be attributed to northern migrants (Okladnikov, Medvedev, Filatova, 2015: 60, 63). Localization of ceramics predominantly in the upper layers confirms the previous idea that these migrants came to Suchu Island later than the Malyshevo people.

The Voznesenovskoye culture (Fig. 3, 30-32, 35, 36) is represented by 773 items: 4 vessels (reconstruction), 72 upper and 8 lower parts, 80 rims, 539 walls, and 70 bottoms. These items have been found in the upper layer (185), in the upper (316) and lower (198) parts of the filling, above the floor (2) and on the floor (64) of the dwelling, in the space between dwellings (2), and also in the Neolithic burial (2). The ceramic paste is from dense to very loose. Using binocular microscopy, it has been established that freshwater mollusks served 


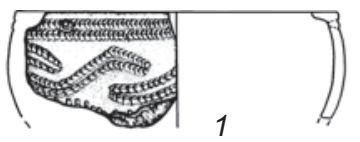

ros
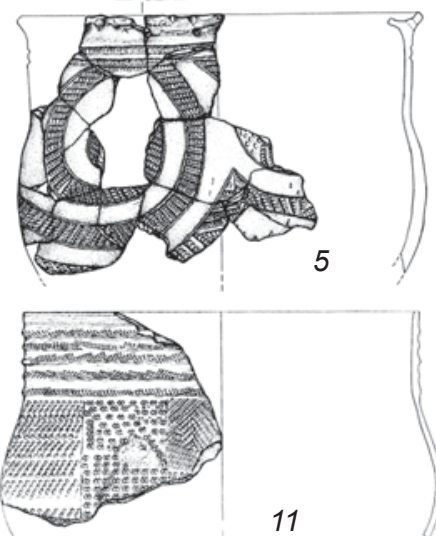

11
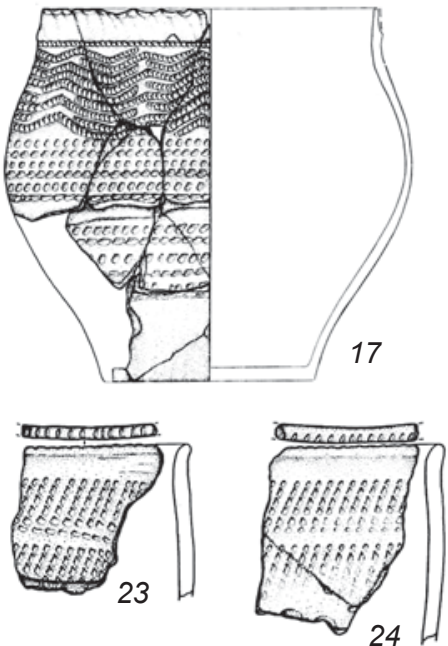

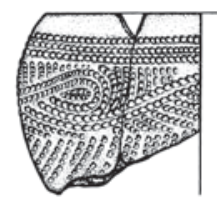

3
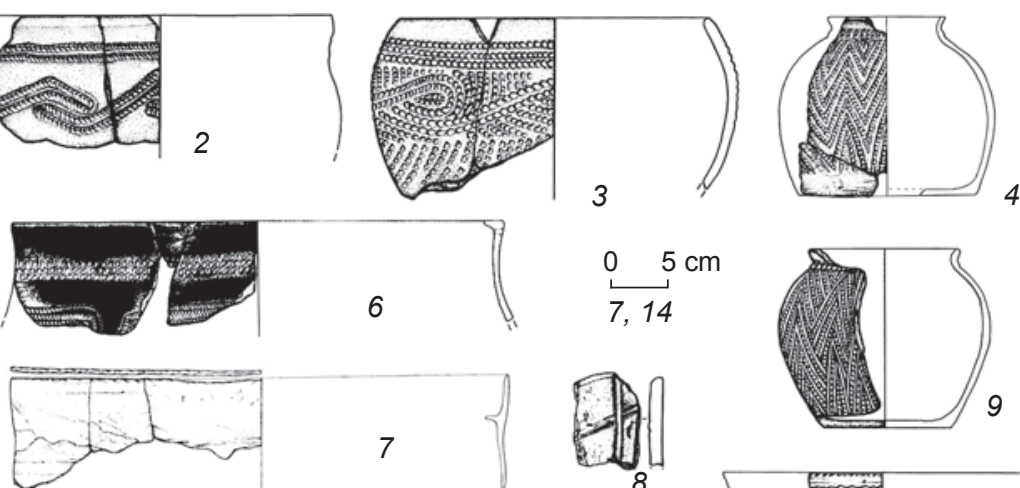

7
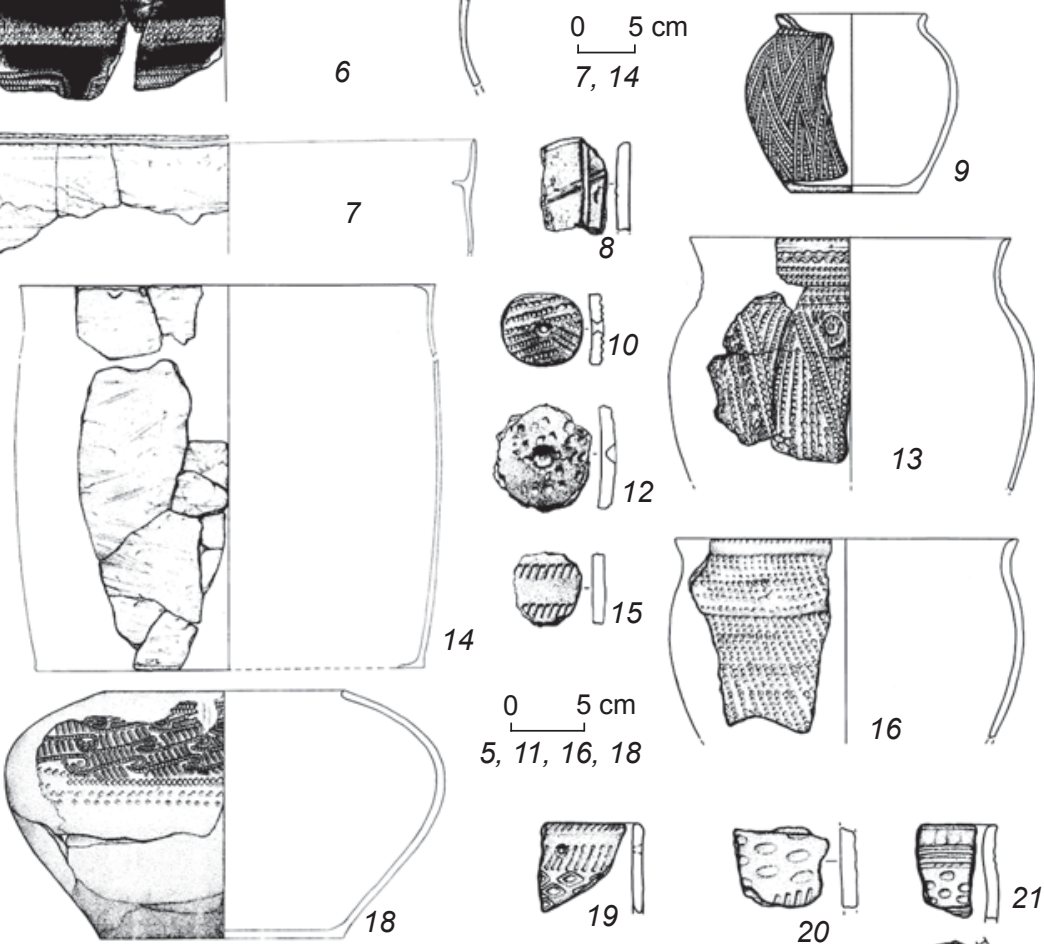

14

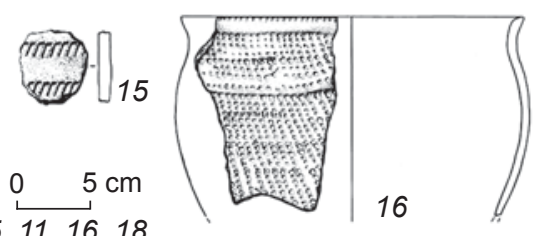

$5,11,16,18$
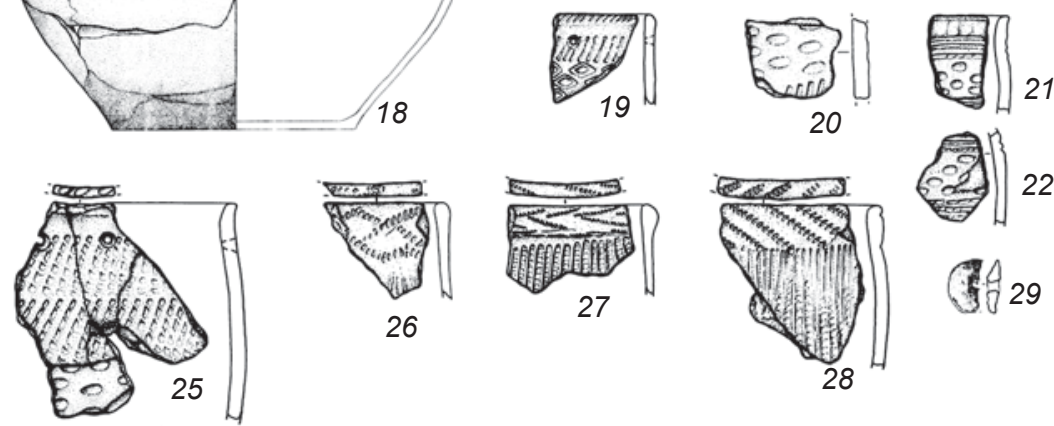

26

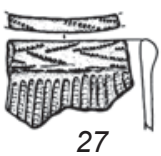

(2) 22

3. 29
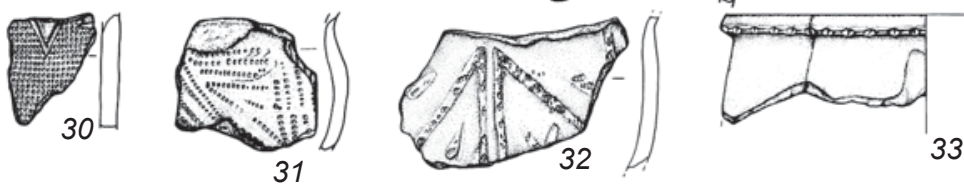

33

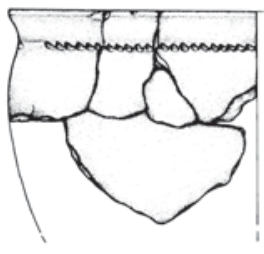

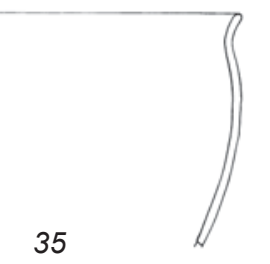

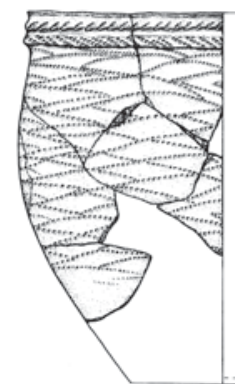

$1-4,8-10,12,13$

$15,19-32,34$
$5 \mathrm{~cm}$

13
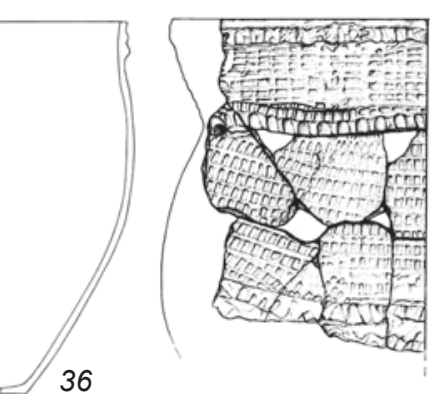

37

Fig. 3. Ceramics.

$1-7,9,11,13,14,16-28,30-37$ - vessels (reconstruction) and their parts; 8 - a burnisher; 10 - a spindle whorl; 12, 15 - blanks of spindle whorls made from walls of vessels; 29 - fragment of a spindle whorl.

1-18 - the Malyshevo culture; 19-25 -the Kondon culture; 26-28 - the Belkachi complex; 29, 33, 34 - the Final Neolithic type; 30-32, 35, 36 - the Voznesenovskoye culture; 37 - the Poltse culture. 
as admixture in "loose" specimens. The vessels were shaped mainly using base-and-body, or more rarely base-, or very rarely body-and-base shaping methods, with coil-ring technique. There are vessels with or without necks; open and closed; small-, medium-, and large-sized. The rims are folded outwards, straight or bent inwards (more rarely), with beveled, rounded, pointed, or flattened mouth cuts. Bottoms are flat. Surfaces of ready items were rubbed, "smoked", more rarely burnished, and covered with engobe. The color of potsherds shows that ceramics were fired in the redox environment.

All ceramics are classified as household utensils. Often, significant soot or carbon deposits are observed on the inner and/or outer surfaces. 429 specimens $(55.5 \%)$ are not ornamented. There are two groups of vessels. The first group includes specimens ornamented along the body with vertical comb zigzags and incised spirals. They are made of dense paste without organic admixture. The paste of the second group is loose, tempered with considerable amounts of freshwater mollusks. These ceramics are subdivided into three basic subgroups in terms of decorative characteristics. The first subgroup shows the presence of smooth fillets along the outer rim's surface, a vertical and/or horizontal zigzag, parallel oblique lines forming angles and triangles; the second subgroup shows fillets cut with flutes and covered with imprints of stepping comb or cogged wheel in the form of "herringbones" or parallel rows along the outer surface of the rim; the third subgroup shows fillets with or without cuts by flutes, covered with imprints of comb, scratches, or incised lines ("cannelures") along the outer surface of the rim; the body is smooth. The diversity of the ceramics allows a conclusion to be drawn about possible repeated waves of migration by the Voznesenovskoye people, starting from the middle stage and ending by the late and final stages of the culture's development.

The Final Neolithic type (Fig. 3, 29, 33, 34) includes 288 specimens: 20 upper and 3 lower parts, 18 rims, 219 walls, and 27 bottoms, as well as a fragment of a spindle whorl. These items have been found in the upper layer (41), in the upper (122) and lower (60) parts of the filling, above the floor (15) and on the floor (47) of the dwelling. Three specimens (an upper portion and 2 walls) were recovered from the Neolithic burial's filling. The paste of the sherds is often dense or more rarely rather loose, tempered with river mollusk shells. The items have closed shapes, with or without (few) necks, and are mostly medium or large in size. Small specimens have been recorded more rarely. The vessels were shaped using coil-ring technique, and also base-, base-and-body, or bodyand-base methods. The rims are folded outwards, mouth cuts are skewed outwards or inwards, flattened or rounded. Bottoms are flat. The surfaces are wellsmoothed and covered with engobe. The colors of the ceramics vary from light to dark brown, gray-brown, gray and dark gray, and dark orange, which suggests redox firing conditions.

The vast majority of items (260 spec., or $90.3 \%$ ) are not ornamented. Only rims are decorated: either with an appliquéd rib extending in the middle or in the lower portion of the outer part of the rim, or with an appliqué having one or two flutes forming polished fillets. The household purpose of the ceramics is evidenced not only by soot and carbon deposits on the surfaces of the sherds, but also by the fact that one rim-fragment was used as a burnisher. The Final Neolithic pottery is a uniform complex with similar characteristics. Its relatively small amount suggests the brevity of the functioning (apparently in the first quarter of the 2nd millennium BC) of the settlement during this Neolithic stage.

Noteworthy are several potsherds from the excavation area that are not identified with the Neolithic Amur assemblages. These have some resemblance to the Middle Neolithic pottery of Sakhalin Island in terms of their technology (admixture of shells) and decoration (rope and cord imprints, linear incisions) (Vasilevsky, 2008: 376, fig. 100, 2, 3).

Apart from the described Neolithic pottery, later ceramics have also been recorded ( $88 \mathrm{spec}$.). Four sherds of rims and nine fragments of walls of various vessels, ornamented with imprints of three- and six-cogged comb, bracket-like and rectangular impressions, oval pricks, incised grooves, and appliquéd straight fillets, probably pertain to the Bronze Age. These sherds have been found in the upper layer of the excavation area and in the upper part of the dwelling's filling.

Two vessels (reconstruction) and 67 fragments of Poltse pottery belong to the Early Iron Age (Fig. 3, 37). The vessels are closed, with necks, medium or large in size. The rims are folded outwards, mouth cuts are rounded. There is a specimen with a typical saucershaped rim. The bottoms are flat, with flanges. The majority of items are decorated with straight or wavy appliquéd fillets, finger or textile impressions, comb imprints, or incised grooves.

The Middle Ages are represented by several unornamented fragments of wheel-turned gray clay pottery belonging to the Jurchen culture of the 11th13 th centuries. Another two sherds (a rim and a 
handle) pertain to the ethnographically contemporary period. These are not ornamented, and are covered with glaze.

Thus, the majority of the described ceramics $(81.3 \%)$ correlate with the Malyshevo pottery tradition (the developed stage) of the Middle Neolithic. These finds are related mainly to dwelling $B$, which determines the dwelling's cultural and chronological attribution. However, the context of the occurrence of certain ceramics indicates that the foundation pit of the Malyshevo dwelling may have been used by people from other non-contemporaneous archaeological cultures. This suggests permanent migrations by human communities that visited the island, starting from the earliest stages of the Middle Neolithic and up to the ethnographically contemporary period. Some migrants were of different origin with respect to the population of the region under study, and had different points of exit: continental Asia and Pacific islands.

\section{Objects of art and cult}

The collection of objects of art and cult (Fig. 4) comprises various items made of burnt clay ( $34 \mathrm{spec}$.) and stone ( 3 spec.). Clay items include threedimensional zoo-, ornitho- and anthropomorphic images (four intact ones and seven fragments), ten discoidal items of churinga type decorated with concentric circles, spirals, meander, and masks; an ornamented ball and a smooth small ball, phallic rods (three splinters), and a pendant blank. Also, three ornamenting tools in the form of cogged wheels, and four small vessels from the burial are included here. Stone items are fragments of two hybrid (gynandromorphic) "male-female" sculptural representations, and a piece of a ring-pendant made of white jade (Medvedev, Filatova, 2018b: 80, fig. 5, $4,11)$. All of these belong to the Malyshevo culture. Many of these finds were earlier described in detail

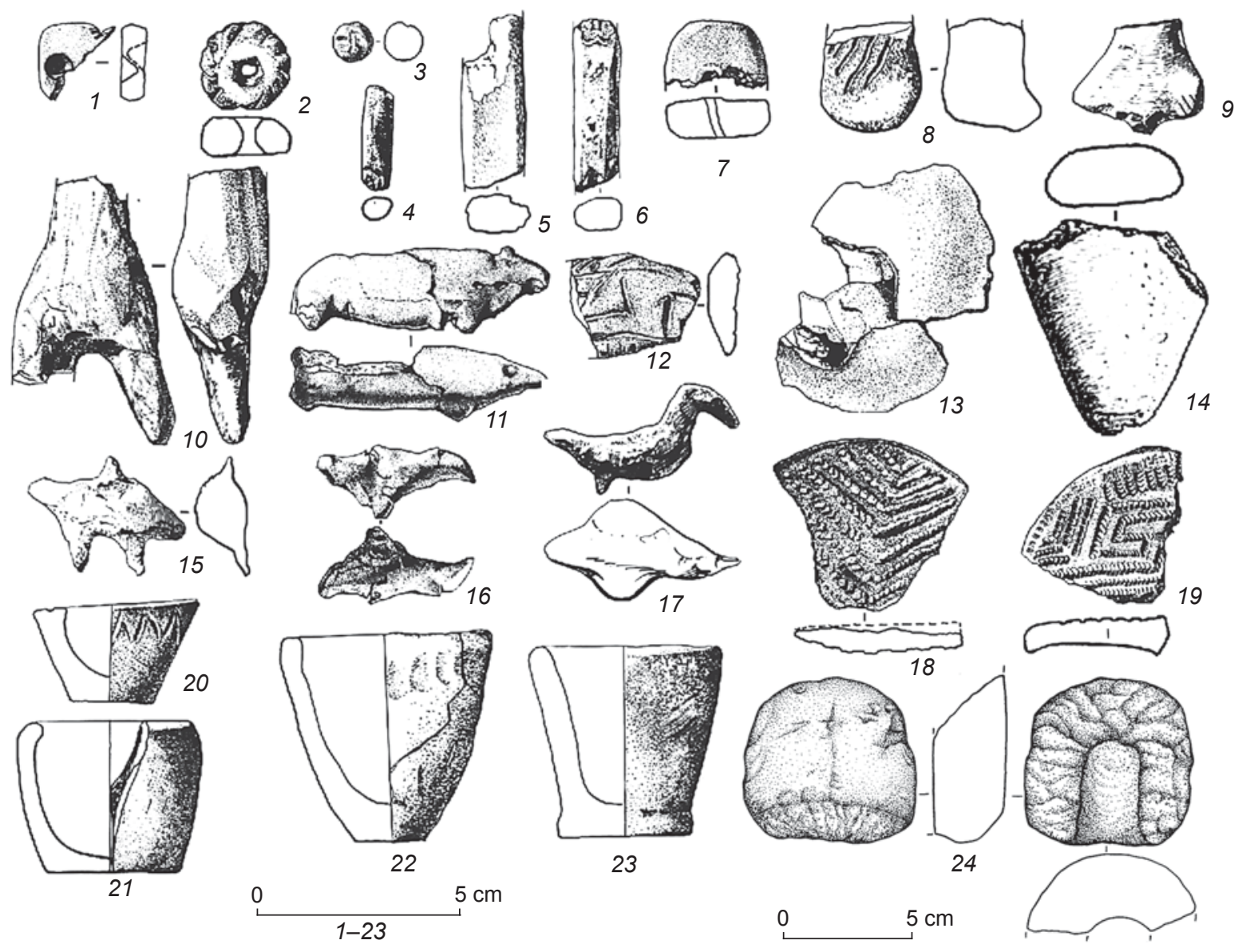

Fig. 4. Objects of art and cult of the Malyshevo culture.

1 - a blank for a pendant; 2 - a stamp; 3 - a ball; 4-6 - ceramic rods; 7-11, 13-17, 24 - sculptural representations $(7-10,13,14$, 24 - anthropomorphic, 11,12, 15 - zoomorphic, 16, 17 - ornithomorphic); 12, 18, 19- churingas; 20-23 - small vessels from the Neolithic burial. 
in special publications (Derevianko, Medvedev, 1996: 218-219; Medvedev, 2000, 2002, 2009, 2011).

\section{Conclusions}

The results of comprehensive study of the excavation materials from an ancient dwelling on Suchu Island (excavation area I, 1975) are presented for the first time. In the excavation area embracing the depression of half-dugout dwelling $B$, the cultural layer (predominantly, sandy-loam) above the pit floor reached $3 \mathrm{~m}$. The foundation pit with a round shape in plan view, with a maximum diameter of $16 \mathrm{~m}$, was deepened by more than $1 \mathrm{~m}$ into bedrock sand. The dwelling arrangement has no fundamental differences from other Neolithic residential buildings of Suchu and the Amur basin. It also has a well-pronounced foundation pit-an underground part, where people stayed during the cold season. A large number of pits from the posts constituting the support-base of the dwelling's structure are located along the walls and at other dwelling-places. Earthen sleeping ledges arranged along the walls are common in the majority of Lower Amur Neolithic dwellings. At the center of the halfdugout, there was a hearth.

At the same time, dwelling $B$ has certain distinctive features. Despite its large size (about $260 \mathrm{~m}^{2}$ along the outer contour), the floor proper was a flat roundsquare area of slightly more than $8 \mathrm{~m}^{2}$ at the center of the half-dugout. All remaining space around it was occupied by five or six steps arranged in the manner of an amphitheater. These ledges, often blurred and smoothed, probably served as bunk beds and shelves for the inhabitants of the dwelling. At several places, there were pits dug on the steps, as some sort of "niches". As for the appearance of the half-dugout, its shape obviously resembled a strongly truncated or flattened pyramid.

Lithics, ceramics, objects of art, and ritual items were found at the site. The earlier undescribed archaeological materials were studied using several methods: morphotypology, binocular microscopy, and cultural chronology. The recovered ceramic pieces have been mostly attributed to the Middle (Malyshevo and Kondon cultures, and the Belkachi complex), Late (Voznesenovskoye culture), and Final (Final Neolithic type) Neolithic periods. There are also items belonging to later times (the Bronze Age, the Early Iron Age, and the Middle Ages); ceramic specimens untypical of the Amur archaeological cultures have been noted. Morphotypological analysis of the lithics has demonstrated the presence of various tools and hunting/fishing instruments, as well as primary reduction materials. Cultural and chronological analysis suggested the attribution of rather unusual objects of art and cult primarily to the Malyshevo (the developed stage) cultural tradition.

Noteworthy are two recorded burials that were arranged inside dwelling $B$ after it had been abandoned (in the Neolithic and in the Early Iron Age). Data on ancient burials, almost unknown in the region (not a single one dating to the Neolithic was known until the present time), as well as all the materials obtained in the excavation area, are especially relevant for reconstruction of the cultural and historical processes that took place in the Amur basin in the Middle Neolithic and later.

Two radiocarbon dates have been obtained for dwelling $B: 4380 \pm 40 \mathrm{BP}(\mathrm{SOAN}-1280)$ and $4650 \pm 55$ BP (SOAN-1281) (Orlova, 1995: 226). This allows its attribution to a time no later than the end of the 3rd millennium BC.

\section{Acknowledgements}

This study was performed under the R\&D Program, Project No. 0329-2018-0001 "Occupation of Northern Asia by the Early Humans: Cultural and Ecological Context”. O.S. Medvedeva (text) and Y.V. Tabareva (drawings) took part in the preparation of this paper.

References

\section{Derevianko A.P., Medvedev V.E. 1996}

Ostrov Suchu — unikalniy pamyatnik arkheologii Dalnego Vostoka. In Arkheologiya Severnoy Pasifiki. Vladivostok: Inst. istorii, arkheologii i etnografii narodov Dalnego Vostoka Dalnevost. otdeleniya RAN, pp. 214-221.

\section{Derevianko A.P., Medvedev V.E. 2002}

$\mathrm{K}$ tridtsatiletiyu nachala statsionarnykh issledovaniy na ostrove Suchu (nekotoriye itogi). In Istoriya i kultura Vostoka Azii: Materialy Mezhdunar. nauch. konf., vol. 2. Novosibirsk: Izd. IAET SO RAN, pp. 53-66.

\section{Medvedev V.E. 2000}

New motifs of the Lower-Amur Neolithic art and associated ideas of the ancient people. Archaeology, Ethnology and Anthropology of Eurasia, No. 3: 56-68.

Medvedev V.E. 2002

Amurskiye churingi. Gumanitarniye nauki v Sibiri. Ser.: Kultura, nauka, obrazovaniye, No. 3: 11-15.

Medvedev V.E. 2009

Clay balls from Suchu island as Neolithic sacral symbols. Archaeology, Ethnology and Anthropology of Eurasia, vol. 37 (3): 41-49. 


\section{Medvedev V.E. 2011}

Skulpturniye izobrazheniya s ostrova Suchu. In Drevnosti po obe storony Velikogo okeana. Vladivostok: Izd. Dalnevost. Federal. Univ., pp. 8-15. (Tikhookeanskaya arkheologiya; iss. 21).

\section{Medvedev V.E. 2017}

$\mathrm{Ob}$ osobennostyakh razvitiya srednego i pozdnego neolita na yuge Dalnego Vostoka (Nizhneye Priamurye). In Trudy V (XXI) Vserossiyskogo arkheologicheskogo syezda v Barnaule-Belokurikhe, vol. 1. Barnaul: Izd. Alt. Gos. Univ., pp. 155-158.

\section{Medvedev V.E., Filatova I.V. 2016}

Tentative findings from excavations on Suchu island, Amur (1973 season, excavation I). Archaeology, Ethnology and Anthropology of Eurasia, vol. 44 (4): 24-37.

\section{Medvedev V.E., Filatova I.V. 2018a}

A study of finds from excavation I at Suchu island, the Lower Amur (the 1974 field season). Archaeology, Ethnology and Anthropology of Eurasia, vol. 46 (4): 22-32.

Medvedev V.E., Filatova I.V. 2018b

Kamenniy inventar poseleniya Suchu (1975 god, raskop I, zhilishche C). Teoriya i praktika arkheologicheskikh issledovaniy, No. 3: 71-84.

\section{Okladnikov A.P. 1973}

Otchet o raskopkakh neoliticheskogo poseleniya na ostrove Suchu Khabarovskogo kraya v 1973 g. Arkhiv IA RAN. R-1. No. 5072.

\section{Okladnikov A.P. 1980}

O rabotakh arkheologicheskogo otryada Amurskoy kompleksnoy ekspeditsii v nizovyakh Amura letom 1935 g. In Istochniki po arkheologii Severnoy Azii: 1935-1976 gg. Novosibirsk: Nauka, pp. 3-52.

\section{Okladnikov A.P., Medvedev V.E., Filatova I.V. 2015}

The first systematic excavations on Suchu Island and radiocarbon dates of the site (1972). Archaeology, Ethnology and Anthropology of Eurasia, vol. 43 (3): 50-63.

Orlova L.A. 1995

Radiouglerodnoye datirovaniye arkheologicheskikh pamyatnikov Sibiri i Dalnego Vostoka. In Metody estestvennykh nauk $v$ arkheologicheskikh rekonstruktsiyakh, pt. 2. Novosibirsk: Izd. IAET SO RAN, pp. 207-232.

Vasilevsky A.A. 2008

Kamenniy vek ostrova Sakhalin. Yuzhno-Sakhalinsk: Sakhalin. kn. izd. 